\title{
SUSTAINABLE MANAGEMENT OF NIGERIA'S OIL WEALTH: LEGAL CHALLENGES AND FUTURE DIRECTIONS
}

\author{
Solomon Ekokoi*
}

\begin{abstract}
Oil is a very important resource for Nigeria, as it remains the major economic driver and mainstay of the country. The unsustainable management of Nigeria's oil wealth, rather than the availability of oil itself, remains the real cause of the challenges confronting the economic performance of the country. This article contributes to the debate on how Nigeria can develop more coherent and sustainable practices in the management of its oil wealth. It examines how policies and rules of law that promote mismanagement, corruption, waste and the fixation with the sharing of oil revenues at the expense of production are unsustainable and unethical practices that may continue to stifle sustainable development in Nigeria. The article discusses the need for stronger legal regimes for the efficient management of Nigeria's oil wealth, and identifies the roles that active stakeholder engagement, such as the Nigerian public and civil society organizations (CSOs) should play.
\end{abstract}

Keywords: CSOs, sustainable management, oil wealth, mismanagement, State theft, economic development.

DOI: http://dx.doi.org/10.4314/jsdlp.v7i2.7

The spirit of a people, its cultural level, its social structure, the deeds its policy may prepare - all this and more is written in its fiscal history, stripped of all phrases. He who knows how to listen to its message here discerns the thunder of world history more clearly than anywhere else, ${ }^{1}$ [and recognizes the inevitability of]

* Lecturer in Law, Department of Public Law, Faculty of Law, University of Uyo, Nigeria; e-mail: emmanuelsolomon@uniuyo.edu.ng; ekokoisolomon@yahoo. com. The author is grateful to the anonymous reviewers for their useful comments on the earlier draft. However, any error is the responsibility of the author.

1 J. A. Schumpeter, quoted in I. W. Martin, A. K. Mehrotra and M. Prasad, 'The Thunder of History: The Origins and Development of the New Fiscal Sociology' in I. W. Martin, A. K. Mehrotra and M. Prasad, The New Fiscal Sociology: Taxation in Comparative and Historical Perspective (eds) (Cambridge University Press 2009) 1. 
[t]he present that was the future in society's past [becoming] ... the past of society's next future. ${ }^{2}$

\section{INTRODUCTION}

This article begins with an epigraph by Joseph Schumpeter and Philip Allot which could serve as a mantra for the 'fiscal sociological scholarship's $^{3}$ on the sustainable management of Nigeria's oil wealth. The article does not attempt to underplay the contributions of non-oil sectors to the Nigerian economy. ${ }^{4}$ However, oil remains a very important resource for Nigeria and its major economic driver. ${ }^{5}$ There is even the claim that oil is at the core of Nigeria's corporate existence as its social, economic and political milieu revolves around crude oil. ${ }^{6}$ This raises the question whether the political and economic history of Nigeria would have been different if oil were discovered a decade earlier or not discovered at all. Inherent in this notion is a sad commentary as ' $\mathrm{t}$ ] he idea is essentially repulsive of a society held together only by relations and feelings arising out of pecuniary interest."

There is also the notion that oil resource can be an excellent key to unlocking social change; and that is a strong motivation for this article. This idea derives from the realization that oil contributes huge revenues to the Nigerian State. The revenues should be exchanged for other

2 P. Allot, 'Reconstructing Humanity: New International Law' (1992) 3 E.J.I.L 219, 224.

3 E.S. Lieberman, 'The Politics of Demanding Sacrifice: Applying Insights from Fiscal Sociology to the Study of AIDS Policy and State Capacity' in I. W. Martin, A. K. Mehrotra and M. Prasad, The New Fiscal Sociology: Taxation in Comparative and Historical Perspective (eds) (Cambridge University Press 2009) 101.

4 The solution to Nigeria's economic non-performance appears to be beyond economics per se, as the country's seem to have defied economic rules and principles. See O. Famuyiwa, 'The Nigerian Financial Crisis: A Reductionist Diagnosis' (2013) 2 (1) Afe Babalola University: Journal of Sustainable Development Law and Policy36-64.

5 L. N. Chete et al, 'Industrial Development and Growth in Nigeria: Lessons and Challenges' (Learning to Compete, Working Paper No. 8, Nigerian Institute of Social and Economic Research (NISER), Ibadan 2016) $1<$ www.brookings.edu/ wp-content/uploads/2016/07/L2C_WP8_Chete-et-al-1-pdf> accessed 20 August 2016.

6 ibid.

7 J. S. Mill, Principles of Political Economy with Some of the Applications to Social Philosophy (W Ashley (ed)7th edn, Longmans, Green and Co. 1909) 754. 
public goods and services, for public finance has an institutional basis for modernity and progress. ${ }^{8}$ Therefore, it is the best starting point for an investigation of Nigeria's social, economic and political life. However, the unsustainable manner in which Nigeria's oil wealth has been managed over the years has made life unbearable for the millions of vulnerable citizens - those who live below the poverty line. Chinua Achebe once observed that living life without having the things with which to live it well is akin to 'a kind of slow and weary life which is worse than death. ${ }^{10}$ This suggests that the sustainable management of Nigeria's resource-based wealth entails that conditions of poverty and inequality will be alleviated. Moreover, the failure to do so would render the concept of sustainable development meaningless, as the concept encompasses 'development as well as sustainability. ${ }^{11}$ According to Martin Holdgate, to understand development is to recognize the potential of resources. ${ }^{12}$ Therefore, the recognition of the link between development and sustainable resource management should be seen as imposing a normative obligation on the Nigerian State as the provider of social protection in its capacity as 'the contemporary parens patriae', ${ }^{13}$ as distinct from the ethical necessity not to transfer the burden of the failure of the present generation to future generations. Despite the link that may exist between oil resource and economic development, there is the problem of disconnect in the dynamic relationship between the citizens and the Nigerian State as ' $\mathrm{t}$ ] axation is perhaps the only [S] tate policy that can be counted on to generate frequent resistance throughout history and all over the world. ${ }^{14}$

The question may then be asked: What amounts to sustainable management of Nigeria's oil wealth? Sustainability denotes the ability to create 'the possibility for achieving overall well-being for the present

8 Martin, Mehrotra and Prasad (n 1) 5.

9 J. S. Mill quoted in Martin, Mehrotra and Prasad (n 1) 2.

10 Chinua Achebe, Arrow of God (Heinemann Ltd 1989) 95.

11 R. Ciegis, J. Ramanauskiene and B. Martinkus, 'The Concept of Sustainable Development and its Use for Sustainability Scenarios' (2009) 2 Inzinerine Ekonomika-Engineering Economics 28, 29.

12 M. W. Holdgate, 'The Sustainable Use of Tropical Coastal Resources: A Key Conservative Issue' (1993) 22 AMBIO, 481-482

13 . Famuyiwa, 'Forum Issues in the Enforcement of Regulatory Obligations of the Nigerian Public Companies' (2015) 5 (1) Afe Babalola University: Journal of Sustainable Development Law and Policy 72, 74.

14 Martin, Mehrotra and Prasad (n 1) 2-3. 
and the future generations' of society. ${ }^{15}$ It can also be described in terms of long-term and continuous satisfaction of human needs through rational usage and replenishment. ${ }^{16}$ The essence of the concept of sustainability is the creation of social and economic systems which have the capacity to support an increase in real income, the improvement of the level of education, improvement in the health of the population and the general quality of life, as they constitute the 'ethical ideal and normative ethical principle for the further development of the society, that speaks not about the way it is but the way it should be'. ${ }^{17}$ Therefore, sustainable management of Nigeria's oil wealth should involve a holistic system that can develop towards greater benefits for the citizens, increased efficiency in resource utilization and inter-generational equity. It postulates resource management systems which are capable of satisfying the needs of the present generation without depriving future generations of satisfying their own needs, ${ }^{18}$ based on preferred development models of the State which must commit to improved economic performance of society through interventions and directions and for sustained economic growth. ${ }^{19}$

This article argues that oil is not the problem of the Nigerian State but the unsustainable manner in which the oil wealth has been managed over the years. The article focuses on some policy and legal issues, which pertain to sustainability in relation to the enormous oil revenues collected by the Nigerian State. It also identifies issues pertaining to leakages of oil resources, which translate into huge losses in oil revenues. Both categories of challenges are occasioned by policies and political enterprises, which are permitted by the absence of sound legal regimes. Arguably, the unsustainable management of Nigeria's oil wealth is a phenomenon that gives rise to what Michael Ross described as a

15 R. Ciegis, J. Ramanauskiene and B. Martinkus (n 11) 30.

16 Damilola Olawuyi, Principles of Nigerian Environmental Law (Afe Babalola University Press, 2015) 1-15; also Declaration of the UN Conference on Environment and Development, UN Doc. A/CONF.151/26/Rev.1, Report of the $U N C E D$ vol. 1 (New York) [Rio Declaration on Environment and Development, 1992].

17 Ciegis, Ramanauskiene and Martinkus (n 11) 30.

18 The World Commission on Environment and Development, Our Common Future Oxford University Press 1987).

19. S. Ghebremusse, 'New Directions in African Developmentalism: The Emerging Developmental State in Resource-Rich Africa' (2016) 7 (1) Afe Babalola University. J. of Sust. Dev. Law \& Policy1, 9. 
'disappointingly average' economic performance. This results from the failure of the Nigerian State to use the gains from oil resources to generate economic opportunities for its citizens, stimulate the growth of per capita income, as well its inability to surmount the challenges created by oil revenue volatility. ${ }^{20}$

It has been suggested that many resource-rich African States lack the character of a developmental State. ${ }^{21}$ This argument applies to Nigeria, as the sustainable management of its oil wealth has become notoriously problematic. ${ }^{22}$ To this extent, this article examines some of the factors that exacerbate the unsustainable management of the nation's oil wealth.

The article is divided into seven sections. After this introduction, section 2 provides a review of some social and economic challenges confronting the Nigerian society despite its vast oil and gas endowment. Section 3 identifies the inadequacy of legislation in the regulation and management of the country' soil wealth, and the social implications for the country. Section 4 adopts the politico-historical analysis to examine the impact of revenue allocation on the sustainable management of Nigeria's oil revenues. Section 5 examines the high cost of governance in the country through the prism of wasteful and corrupt policies. In section 6, the future direction for the sustainable management of Nigeria's oil wealth is examined. Section 7 is the conclusion.

\section{THE OIL BLESSING OR CURSE: SOCIAL AND ECONOMIC CONSEQUENCES OF OIL WEALTH MISMANAGEMENT IN NIGERIA}

There is a large body of literature on the history of oil in Nigeria. ${ }^{23}$

20 M. L. Ross, The Oil Curse: How Petroleum Wealth Shapes the Development of Nations (Princeton University Press 2012) 13.

21 Ghebremusse (n 19) 22-23.

22 M. Watts, 'Resource Curse? Governmentality, Oil and Power in the Niger Delta, Nigeria' (2004) 9 (1) Geopolitics 50.

23 For an historical account of oil in Nigeria, see D. Olawuyi, Principles of Nigerian Environmental Law (Afe Babalola University Press 2015) 1-30; Y. Omorogbe, Oil and Gas Law in Nigeria (Malthouse Press Limited 2001) 16-9; K. S. A. Ebeku, Oil and the Niger Delta Peoples in International Law: Resource Rights, Environmental and Equity Issues (OGEL Special Study - Vol 5, Alexander's Gas \& Oil Connections and Oil, Gas \& Energy Law Intelligence, February 2005) 88102. 
Therefore, this subject will not be examined in this article. It is important to underscore the social and economic challenges of poverty, unemployment and the dearth of social infrastructure which confront Nigeria, the biggest oil exporter with the largest natural gas reserves in Africa $^{24}$ and one of the largest in the world. Industry records show that Nigeria has 'an estimated 159 trillion cubic feet of proven natural gas reserves', ${ }^{25}$ which is mostly flared due to an acute lack of utilization infrastructure. Statistical data related to gas flaring is unreliable, but it is estimated that Nigeria loses US\$ 18.2 million daily due to gas flaring. ${ }^{26}$ This is in addition to the environmental damage associated with the practice. ${ }^{27}$ According to the World Bank, Nigeria accounts for about 12 percent of the total gas flared in the world. One projection by the United States (US) Energy Information Administration places Nigeria's oil reserves between 16 and 22 billion barrels. Yet, Nigerian policy makers continue to act as though oil resource will endure forever.

The social and economic challenges confronting the Nigerian society have been attributed largely to the unsustainable management of the revenues from oil resource. ${ }^{28}$ The end of the civil war in 1970 coincided with the rise in global oil price. However, Nigeria failed to use the revenues from the so-called 'oil boom' efficiently. As this article argues in section 5, government's expenditures (not on social and economic infrastructure) continue to expand significantly faster than the economy. This inverted process is encouraged, for example, by the unnecessary expansion of the bureaucracy which results in bloated administrative centres with little or no corresponding social and economic development to show for it, and the mismanagement, waste, and corruption in the governing process. It has been argued that the increase

24 The World Bank, 'Nigeria: Overview' (30 September 2015) <www.worldbank. org/en/country/nigeria/overview> accessed 21 August 2016.

25 Nigerian National Petroleum Corporation, 'Development of Nigeria's Oil Industry' < www.nnpcgroup.com/NNPCBusiness/BusinessInformation/ OilGasinNigeria/DevelopmentoftheIndustry.aspx> accessed 23 July 2015.

26 Online Nigeria Portal, 'Nigeria - Natural Gas'<www.onlinenigeria.com/links/ petradv.asp?blurb=486> accessed 21 July 2015 .

27 Gbemre v SPDC (Suit No. FHC/B/CS/53/05, 14 November 2014) [Unreported].

28 Damilola S. Olawuyi, Principles of Nigerian Environmental Law (Afe Babalola University Press, 2015) 15-40. See also Damilola S.Olawuyi, 'The Increasing Relevance of Rights-Based Approaches to Resource Governance in Africa: Shifting from Regional Aspiration to Local Realization' (2015) 11 (2) McGill International Journal of Sustainable Development Law and Policy 293-338. 
in administrative centres, as demonstrated in the creation of new states from the existing ones was a deliberate policy to address the marginalization of ethnic minority groups in Nigeria as well as promote economic development. ${ }^{29}$ This policy has since been jettisoned as evident in its ideological reversal. ${ }^{30}$ This argument is difficult to accept, as the creation of new states in Nigeria appears to be a means of distributing what is often called the national cake. ${ }^{31}$

Very little is known about how much oil is actually produced in Nigeria. This is a highly secretive issue, which has given rise to corrupt practices and or resource capture, especially in the offshore operation of the oil and gas sector. ${ }^{32}$ Nigeria is known to have one of the world's richest deep-water oil reserves. Regrettably, details from the leaked Panama Papers reveal how oil revenues from Nigeria's offshore production disappear. ${ }^{33}$ It is also on record that the sum of US\$ 12.4 billion, part of the revenues, which accrued from oil transactions between 1988 and 1992, has never been properly accounted for. This is what gave rise to the 2012 case of Socio-Economic Rights Action Project \& Ors v Governor, Central Bank of Nigeria \& Attorney General of the Federation, a suit filed at the Federal High Court, Abuja, by six CSOs under the Fundamental Rights (Enforcement Procedure) Rules 2009.

In its judgment, the Court held that the plaintiffs lacked the locus standi to institute the case. It also held that Socio-Economic Rights

29 Ebeku (n 23) 58.

30 As 'the creation of states has ceased to be solely a response to minority problem and has become a means of the majority groups trying to adjust again in order to square up.' See Constituent Assembly Debates, 16 March 1978, col. 6764.

31 K. Panter-Brick (ed), Soldiers and Oil: The Political Transformation of Nigeria (Frank Cass 1978) 5, wherein it was argued that '[a] greater share of the federally distributed revenues could be obtained simply by multiplying the number of units of government, each of which could then claim its equal share of the national cake.' This situation, according to W Graf, The Nigerian State: Political Economy, State, Class and Political System in Post-Colonial Era (James Curry 1988) 139, 'developed in the context of the oil boom of the 1970s [when] groundnuts, cotton, cocoa, palm oil etc. ... were replaced by a common dependence on oil revenues.'

32 Y. Alli, 'Ex-Head of State, Others Named in N1.09b Oil Deal' The Nation (Abuja, 29 August 2016) 1, 6.

33 K. Sharife, 'How Nigeria's Lucrative Oil Profits Disappear' ANCIR (2016) <panamapapers.investigativecenters.org/Nigeria-oil/> accessed 3 August 2016. 
Action Project (SERAP) and other CSOs failed to prove the existence of consolidated and special accounts in the Central Bank of Nigeria (CBN) into which the proceeds from the said sale of oil was paid. The Court further held that the CSOs failed to prove how the existence of such a consolidated account in the CBN infringed on their fundamental human rights, noting that their action amounted to being busy bodies. Decisions of this nature by courts of law, which have tenaciously held on to formalistic and legalistic interpretations of the law, are replete in Nigeria where the courts question the rights of citizens to demand transparency and accountability in governance. With due respect to the Court, it is submitted that where the government fails in the provision of adequate public goods to the citizens, to the extent that CSOs and private citizens engage in their provision or contribute to social welfare services, they should have the moral and legal rights to advocate on behalf of the citizens who are deprived and denied social services, ${ }^{34}$ irrespective of anachronistic provisions of the law.

By mid-2001, it is reported that Nigeria's crude oil production averaged 2.2 million barrels per day and there were plans to increase production to between 3 million and 4 million barrels per day by $2010^{35}$ and 2015, respectively. Notable is the claim that production stagnated around 2.1 million barrels per day as of 2014. Ranging at about 73 per cent, Nigeria has been described as one of the countries with the highest government take from oil production. ${ }^{36}$ Government take is the percentage of net revenue from the production of crude oil received by the State. It is estimated that Nigeria generated approximately US\$ 340 billion from oil between 1956 and 2006, ${ }^{37}$ and allegedly lost about US\$ 380 billion between 1960 and 1999. Moreover, it is estimated

34 R. Ako and E. O. Ekhator, 'The Civil Society and the Regulation of the Extractive Industry in Nigeria' (2016) 7 (1) J. of Sust. Dev. Law \& Policy (Afe Babalola University) 183, 186.

35 However, this has not been feasible as the figures provided by the Nigerian National Petroleum Corporation, the Central Bank and the accountant general of the Federation show that oil output and exports have been in steady decline since 2010. See The World Bank, Nigeria Economic Report (No. 2 July 2014) 5.

36 The figure for Ghana is 52 per cent, Karzakhstan 61 per cent, Russia 65 per cent, United Arab Emirates 77 per cent and Angola 83 per cent. See P Atuanya and O. Bello, 'PIB: Critiques Outline Concerns' Business Day (Lagos, 23 July 2012) 4.

37 R. Ako and N. Uddin, 'Good Governance and Resource Management in Africa' in F. N. Botchway (ed), Natural Resource Investment and Africa's Development (Edward Elgar Publishing Ltd 2011) 37. 
that as much as US\$ 4 billion to US\$ 8 billion has been lost to political corruption annually since the return to civilian rule in $1999 .{ }^{38}$ The funds lost to graft are largely proceeds from oil transactions.

Regrettably, despite its huge oil endowment, more than half of Nigeria's population of over 170 million live in poverty. ${ }^{39}$ At the national level, for example, statistics show that for 2004 and 2010, relative poverty measurement stood at 54.4 per cent and 69 per cent, and absolute poverty at 54.7 pe $r$ cent and 60.9 per cent. The population of Nigerians living on less than a dollar per day stood at 51.6 per cent and 61.2 per cent in those respective years. ${ }^{40}$ If the rebasing of the country's Gross Domestic Products (GDP) in 2015 is anything to go by, the amount for determining the poverty line now stands at US\$ 1.4 per day. ${ }^{41}$

In the Niger Delta, Nigeria's centre of oil exploration and production, majority of the people live in extreme poverty and horrendous conditions despite the wealth extracted from their lands and waters. ${ }^{42}$ According to one projection by Amnesty International,

38 ibid 337-8.

39 Central Intelligence Agency, 'Nigeria - Economy' in The World Factbook<www.cia.gov/library/publications/the-world-factbook/geos/ ni.html > accessed 22 January 2016; BBC News, 'Nigerians Living in Poverty rise to $61 \%$ ' (13 February 2012) <www.bbc.com/news/world-africa$17015873>$ accessed 24 March 2014.

40 National Bureau of Statistics, 'The Nigeria Poverty Profile Report 2010' (13 February 2012) 5, <www.nigerianstat.gov.ng/> 14 February 2014. Sadly, since the publication of this report in 2012, no other such report has been released by the National Bureau of Statistics. Rather, it released a report on the growth of the Nigerian economy in 2014 after it rebased to have a Gross Domestic Product (GDP) of US\$ 510 billion, in a manner that suggests that economic growth equals socio-economic development. $C f$ The World Bank (n 36) 1 , notes that 'a large number of Nigerians are clustered around the poverty line, implying a high degree of vulnerability for large part of the population.'

41 The World Bank (n 36) 17.

42 Despite the United Nations Environmental Programme (UNEP) Report on the Environmental Assessment of Ogoniland, commissioned by the federal government of Nigeria, it was only on 5 August 2015 that the government approved the implementation of the recommendation on the rehabilitation of the environment component of the report. Other recommendations in the report include the creation of Ogoni restoration authority, creation of environmental restoration fund for Ogoniland, Coordination of multi-stake holders efforts, institutional and regulatory reforms, emergency measures in drinking water and health, environmental and health monitoring, oil spill contingency planning, preventive pipeline surveillance, etc. It is important to note that government immediately began the implementation of the preventive pipeline surveillance because of the implications for the government revenue, however, the other recommendations have not received equal amount of priority. 
70 per cent of the over six million people in the Niger Delta live on less than US\$ 1 per day. ${ }^{43}$ Studies have shown that many villages in the region do not have electricity and drinkable water. Many children do not have access to school or medical facilities. For a sizeable number of the population, clean drinking water is difficult to come by, ${ }^{44}$ and the rate of unemployment is over the roof. This people lack the required work skills to benefit from the oil installations right about them, so most of the plum jobs in the oil industry go to people from outside the local area. The magnitude of the socio-economic crisis thus created later compelled the productive segment of the community to resort to socially destructive 'employment' as a means of livelihood ${ }^{45}$ and to hit back at the parasitic social order in the country. It has been strongly and persistently argued that these social and economic conditions are functions of mismanagement, waste and ineffective policy actions/ inactions as well as corruption.

Some commentators have argued that the resurgence of militant groups in the Niger Delta since 2006 is a consequence of the horrendous social conditions of the area. ${ }^{46}$ This state of affairs has turned the Niger Delta to one of the most militarized zones in the country. It has also reduced Nigeria's oil production capacity and revenues drastically and disrupted investments in the oil and gas industry. This explains why the federal government was forced on 25 June 2009 to adopt an unconditional amnesty policy to enable the militant youths exchange their weapons for financial rewards and/or educational/vocational training. The arrangement has been described as a political bribe given to the oil communities to keep the oil flowing. As expected, three years before the Amnesty Programme was launched, the crisis in the Niger Delta had cost the Nigerian State an estimated sum of US\$ 20 billion in revenues and infrastructure losses. ${ }^{47}$

43 Amnesty International, 'Nigeria: Oil, Poverty and Violence' (2006) <http:// webamnesty.org/library/index/ENGAFR440172006?open\&of=ENG-NGA> accessed 22 November 2014.

44 Ebeku (n 23) 227.

45 R. Boele, H. Fabig and D. Sheeler, 'Shell, Nigeria and the Ogoni: A Study in Unsustainable Development: I. The Story of Shell, Nigeria and the Ogoni People - Environment, Economy, Relationships: Conflict and Prospects for Resolution' (2001) 9Sustainable Development 74-86.

46 Watts (n 22) 50.

47 The Nigerian Voice, 'Counting the Gains of the Amnesty Programme' (15 February 2012) < www.thenigerianvoice.com/nvnews/82773/1/counting-thegains-of-the-amnesty-programme.html> accessed 17 July 2015. 
Ironically, sixty years after crude oil was discovered in Nigeria, oil activities continue to dominate the economy and revenues, accounting for US\$ 41.8 million of the total value of export of US\$ 45.3 million, ${ }^{48}$ and for about 90 per cent and 80 per cent of the country's gross earnings and budgetary revenues, respectively. ${ }^{49}$ It is even more worrisome that Nigeria, a country which produces millions of barrels of crude oil daily, lacks the capacity to refine enough crude oil to meet its local demand of less than 500,000 barrels per day. This puts Nigeria in the shameful position of being a major oil exporter and a major importer of refined oil. ${ }^{50}$

\section{LAWS GOVERNING THE MANAGEMENT OF NIGERIA'S OIL WEALTH}

There is a plethora of legislations that seeks to regulate the oil and gas industry in Nigeria. ${ }^{51}$ Notably, however, there is no law that states how Nigeria's oil wealth should be managed, except as provided in the Nigeria Sovereign Investment Authority (Establishment, etc.) Act 2011 (NSIA Act), ${ }^{52}$ which stipulates that revenues from oil sold above budgetary benchmark should be transferred to three Funds established

48 Organization of the Petroleum Exporting Countries, 'Nigeria: Facts and Figures' (2016) < www.opec.org/opec_web/en/about_us/167.htm > accessed 7 August 2016.

49 N. Ayoola-Daniels, Nigerian Laws, Cases and Materials on Oil and Gas Vol. 1 (Petgas Global Consulting Limited 2008) xxvii; see also The World Bank, Nigeria Economic Report(n 36) 5.

50 This phenomenon is referred to as the 'Dutch Disease', a concept coined by The Economist (26 November 1977) 82-3, after the Netherland's poor management of its natural gas wealth in the 1960s. The concept explains the relationship between the exploitation of natural resources and the productive sectors of the economy. It claims that as revenue inflows from a natural resource (for example petroleum) increases, the productive sectors (such as manufacturing and agriculture) become less competitive. In countries with petroleum resources, the policy of oil revenue-funded spending discourages genuine private sector investments and may result in long term effects of counter-productivity. See S Griffith-Jones and J. A. Ocampo, 'Sovereign Wealth Funds: A Developing Country Perspective' (paper presented at the workshop on Sovereign Wealth Funds, London, February 2008) 18-19.

51 For a compendium of oil and gas legislation in Nigeria, see generally, AyoolaDaniels, Nigerian Laws, Cases and Materials on Oil and Gas Vol. 1 (n 50).

52 Cap N166 Laws of the Federation of Nigeria 2004. 
under the NSIA Act. ${ }^{53}$ In spite of this avoidable lacuna, the Petroleum Industry (PIB) Bill designed to serve as an omnibus legislation providing a 'holistic legal and regulatory framework for the [management of] Nigeria's oil and gas industry, ${ }^{54}$ has suffered repeated setbacks at the National Assembly since 2009.

In monetary terms, the failure to pass a law in the mould of the PIB has resulted in the loss of 'about US $\$ 37$ billion in private sector investments in the oil and gas industry'55 between 2010 and 2015, and an aggregated loss of over US\$ 15 billion annually to the Nigerian State. ${ }^{56}$ In sharp contrast, Ghana, which only recently commenced crude oil exploration and production, has enacted its Petroleum Production and Exploration Act 2016 to replace its earlier statute of 1984. According to Ghana's energy minister, Emmanuel Buah, the 2016 Petroleum Production and Exploration Act would create an enabling as well as an attractive environment for potential investors in the oil and gas sector and provide certainty and transparency in the rules for their operations. ${ }^{57}$

Concerning the general legal framework for the management of Nigeria's oil wealth, there are the Constitution of the Federal Republic of Nigeria 1999 (as amended) ${ }^{58}$ and the obsolete Petroleum Act ${ }^{59}$ to rely on. The Constitution, which is the ultimate law governing oil in Nigeria, merely vests the legal ownership, management and control of oil and natural gas in the federal government of Nigeria to be managed in a manner as determined by Acts of the National Assembly. However, the Constitution does not provide a detailed management framework

53 E. Solomon, 'Legal and Constitutional Evaluation of the Nigerian Sovereign Wealth Fund' (2015)5(1) Journal of Sustainable Development Law and Policy (Afe Babalola University) 101, 105-111.

54 R. Ako and E. O. Ekhator (n 35) 183, 197.

55 R. Kulasingam et al, 'Nigeria: Outlook for the Nigerian Oil and Gas Market' Mondaq (16 September 2015). <www.mondaq.com/Nigeria/x/427554/ Oil+Gas+Electricity/Outlook+For+ The+Nigerian+Oil+And+Gas + Market $>$ accessed 22 August 2016.

56 As noted by Ibe Kachikwu, minister of state for Petroleum Resources. See F. Asu, 'Ghana beats Nigeria, Passes Petroleum Bill' Punch (Lagos, 9 August 2016) <punchng.com/Ghana-beats-nigeria-passes-petroleum-bill/> accessed 17 August 2016.

57 ibid.

58 Cap C23 Laws of the Federation of Nigeria (LFN) 2004 [hereinafter the Constitution or the Nigerian Constitution].

59 Cap P10 LFN 2004, s 1 (1). 
for the administration of Nigeria's oil wealth. The responsibility to fashion a comprehensive management framework for the revenues from oil and gas resources has been left to the National Assembly. For the purpose of clarity, the constitutional provision on the management and control of crude oil is reproduced below:

[T] he entire property in and control of all minerals, mineral gas in and under or upon any land in Nigeria or in, under or upon the Territorial Waters and the Exclusive Zone of Nigeria shall vest in the $[\mathrm{g}]$ overnment of the Federation and shall be managed in such manner as may be prescribed by the National Assembly. ${ }^{60}$

Currently, the National Assembly has failed or refused to exercise its constitutional power despite the notable mismanagement, waste and attendant corrupt practices and processes, which the Nigerian oil and gas sector has come to be associated with. A case in point is the recent futile legislative probes into the administration of fuel subsidies in the aftermath of the January 2012 nationwide protests over government's policy to increase the prices of petroleum products. ${ }^{61}$

The provisions of section 44(3) of the Constitution together with section 1(1) of the Petroleum Actvest the ownership, management and control of oil in all lands in the government of Nigeria, including the territorial waters, continental shelf or Exclusive Economic Zones. It effectively establishes the principle of eminent domain in Nigeria - a principle defined by the Cato Institute as the constitutional power 'enabling governments to take property from one owner, often small and powerless, and transfer it to another, often large and politically [stronger], all in the name of economic development ${ }^{62}$ or improved economic performance. Yet, there is an abysmally poor economic performance to justify the continued implementation of the policy of eminent domain in Nigeria. Economic development can be said to exist only when the State seriously tackles and drastically reduces poverty,

60 Nigerian Constitution, s 44 (3).

61 The Nigerian government policy to increase the prices of locally consumed petroleum products has been associated with the claim of subsidies on petroleum products, which has become a greatly debated and highly controversial issue in the polity.

62 Cato Institute, 'Eminent Domain: Its Uses and Abuses' (12 May 2002) < http:/ /www.cato.org/events/020514pf.html> accessed 28 July 2014.

63 Dudley Seers in II Ukpong, The Charms and Perils of the Nigerian Presidential System: A Critical Review of Issues, Performance, and Trends (Vantage Press 1984) 83. 
unemployment, and inequality over time. ${ }^{63}$ It would appear that the principle underlying the management and control of oil and gas is at variance with the principle underpinning the management and control of land in Nigeria, even though both are aimed at achieving the same result or policy outcome. This is so because while the power of management and control of land is vested in the governor of a state, ${ }^{64}$ the ownership, management and control of oil and mineral gas underneath the land is vested in the federal government. ${ }^{65}$ This creates an exception to the general common-law principle of quic quid plantatur solo soloced it (whatever is affixed to the land belongs to the land). ${ }^{66}$ Accordingly, no state government, local government or any person or group of persons, other than the federal government can exercise the power of management and control over oil and gas in Nigeria, including the seabed, the territorial waters or any area that forms parts of the continental shelf or the Exclusive Economic Zone of Nigeria. ${ }^{67}$

Regarding the practice of federalism, it could be argued that vesting in the federal government the legal ownership, and power of management and control over all minerals and mineral oil in Nigeria puts it in a dominant position in relation to the states. This situation is further compounded as the exploration and production of minerals and mineral oil are exclusively within the legislative powers of the federal government. ${ }^{68}$ However, the power of management and control of the revenues accruable from oil and gas appear to have been circumscribed by the legal requirement placed upon the federal government to share the revenues from oil with the states and local governments, with a further requirement to transfer a portion (not less than 13 per cent) to states where oil and gas resources are derived. ${ }^{69}$

64 Land Use Act, Cap L5 LFN 2004, ss 1, 2 (1) (a), \& 5; see also K. U. Ekwere, 'Sustainable Development of Oil and Gas in the Niger Delta: Legal and Political Issues' (PhD dissertation, the Law of the Sea and Maritime Law Institute, University of Hamburg 2009) 23-9; Ebeku (n 23) 115-122.

65 Nigerian Constitution, s 44 and Petroleum Act, s 1.

66 Interpretation Act, Cap I23 LFN 2004, s 18, wherein land is defined to include 'any building and any other thing attached to the earth or permanently fastened to anything so attached, but does not include minerals'.

67 Ayoola-Daniels (n 50) 10.

68 Exclusive Legislative List of the 1999 Constitution, Second Schedule, item 39.

69 Nigerian Constitution, s 162 (1); see Allocation of Revenue (Federal Account, etc) Act, Cap A15 LFN2004, s 1; see also Attorney General of the Federation $v$ Attorney General of Abia State \& 35 Ors [2002] All NLR 72, 114 (Ogundare JSC). 
This system of fiscal federalism is anchored on the philosophy of dual economic systems within a system wherein citizens can expect to realize their social and economic needs. Is this the case with the existing revenue allocation system adopted in Nigeria?

\section{REVENUE ALLOCATION SYSTEM AND THE MISMANAGEMENT OF NIGERIA'S OIL WEALTH}

The Nigerian State is arguably preoccupied with the sharing of oil revenues on the altar of national unity and mutual interdependence, rather than the sustainable management of the oil wealth. ${ }^{70}$ This section examines the political and historical background of Nigeria's fiscal practice. Although revenue allocation dates back to the establishment of the Nigerian State, the rules or principles underlying the system of revenue allocation in the country changed after the discovery of crude oil in 1956. And the change in the underlying principles has impacted on the sustainability of Nigeria's oil wealth. For example, at the National Conference of 2014, which was inaugurated by the Goodluck Jonathan administration on 17 March 2014, issues pertaining to oil and the management of oil revenues became so contentious that it was impossible to reach a consensus on any point relating to oil. Consequently, delegates unanimously agreed not to raise such contentious issues in the final report. ${ }^{71}$ This explains why no mention was made of oil in the final report, a document of 763 pages.

As the events in the Nigerian National Assembly, in respect of the passage of the Petroleum Industry Bill have shown, it appears that sectional interests would not allow the passage of some measures aimed at institutionalizing sustainable management of oil resources in Nigeria. Rather than apply federalism for the effective redistribution of wealth and the realization of social and economic development, the federal system in Nigeria has become a platform for the struggle for the control of oil and the revenues that come from it. Therefore, it would appear that the discovery of oil has not been helpful in promoting national

70 I. Ayu, 'Reflections on Federalism and National Assembly Politics in Nigeria', in J.I. Elaigwu, P. C. Logams, H. S. Galadima (eds) Federalism and Nation Building in Nigeria: The Challenges of the 21st Century (Monograph Series, National Council on Intergovernmental Relations, 1994) 131.

71 Conversation with Akpandem James, assistant secretary on media and communications to the National Conference 2014 (Uyo, 29 June 2015). 
cohesion, federalism and national development in Nigeria. The struggle for the control of Nigeria's oil and gas resources appears to be by ethnic division, entwined with political conflicts which result in political manipulation of the people with the sole aim of determining resource allocation. ${ }^{72}$ To drive home this point, it is important to briefly examine the various revenue allocation epochs in Nigeria and the politics that gave rise to them.

\section{The Era of Devolution}

Nigeria started off with the unitary system of government, and like most other unitary States, intergovernmental relations determined the revenue allocation system. The unitary system lasted between 1946 and 1953, when the Nigeria (Constitution) Order in Council 1946 ((Richards Constitution) and the Nigeria (Constitution) Order in Council 1951 (Macpherson Constitution) were in operation. In 1946, during the pendency of the Nigeria (Constitution) Order in Council 1922 (Clifford Constitution), Sir Sydney Phillipson, Financial Secretary of the Nigerian colony, made recommendations in a report, which later formed the basis for intergovernmental fiscal relations under the 1946 Constitution. This revenue allocation system was later incorporated into two subsequent constitutions. According to the Phillipson report:

The natural and ... desirable development of the new constitution will be towards progressive devolution, and the time may well come when the regions will exercise, within their areas, powers akin to those normally exercised by colonial governments, the general government retaining direct authority in practice only over services not transferred to the regions. ${ }^{73}$

The report, therefore, recommended the gradual evolution to a revenue sharing system mainly based on the derivation principle. It envisaged a situation where each regional government was to be credited with the full amount of the tax collected under the Direct Taxation Ordinance 1940 (as amended). Each region was, in addition,

72 C. U. Uche and O. C. Uche, 'Oil and the Politics of Revenue Allocation in Nigeria' (2004) (African Studies Centre, Working Paper 54/2004) 7 available at $<$ http/ /www.ascleiden.nl/pdf/workingpaper54.pdf> accessed 17 November 2013.

73 Quoted in A. G. Adebayo, Embattled Federalism: History of Revenue Allocation in Nigeria, 1946-1990 (Peter Lang Publishers 1993) 35. 
to receive grants from the other non-direct tax revenues and other public funds of the colonial government in strict proportion to the contribution that the region made to those other revenues. ${ }^{74}$ The report further prescribed the horizontal table for the distribution of revenues amongst the various regions as follows - Northern Region (46 per cent), Western Region (30 per cent), and Eastern Region (24 per cent). This system was based on the estimated relative contribution of the various regions to the colonial government's revenues not declared as regional. ${ }^{75}$ The Philipson Committee Report laid the foundation for the principle of derivation as a basis for the revenue allocation system in Nigeria. It is important to note that during the subsistence of the Richards Constitution, 'customs duties alone contributed over 50 per cent of the total revenue of the Nigerian government. ${ }^{76}$

The constitutional changes occasioned by the arrival of a new governor of Nigeria, Sir John Macpherson, resulted in the setting up of another revenue allocation committee, whose report determined the formulae for intergovernmental fiscal relations under the Nigerian (Constitution) Order in Council 1951 (Macpherson Constitution). The Hick-Phillipson committee report frowned at derivation as the sole principle of revenue allocation and noted that:

The application of the single principle of derivation to the division

74 The preference of Sir Phillipson for the derivation principle was based on his belief that there was need to inculcate in each region, a sense of 'financial responsibility' so that they will all learn to 'cut their coat according to their cloth'. See Dina Committee Report (1967) 7.

75 The unreliability of data, from which the above figures were arrived at, became a rallying point for critics of the Phillipson Report and indeed all subsequent revenue allocation reports. It has, for instance, been noted that: [e] ach Commission has been plagued with statistical problems. From Phillipson (1946) to Adebayo (1977), problems of measurement have seemed insuperable and have wrought havoc to each successive effort at devising a workable formula for [revenue] allocation. In some cases, for example, Phillipson, they led to the abandonment of particular principles; in others, for example, Adebayo, they led to the abandonment of the recommendations. Data on regional consumption of imports became the centre of controversy in the 1950s while data on population took on an additional explosive political significance in the 1960s. Only the data on rents and royalties and export duties were politically neutral; but the allocation of revenue even from these sources crated political controversy' (Okigbo Committee Report, vol. 1, 1978, 15-16).

76 Uche and Uche (n 73) 12. 
of the entire non-declared revenue represented an over-emphasis of the principle of regional self-dependence and tended to obscure the equally valid and perhaps more important principle of the needs of the people viewed as citizens of a united Nigeria [as] the unlimited application of the principle of derivation would be more appropriate in a loose confederation of almost independent states than in a federal constitution of the kind which Nigeria is about to achieve. ${ }^{77}$

Despite the criticism of the principle of derivation as a basis of revenue allocation system under the Richards Constitution, the HickPhillipson committee report did not jettison the derivation principle. It, however, retained it for the allocation of such taxes as could be allocated with simplicity and certainty to the regions. The report recommended that 50 per cent of revenue generated from ascertainable taxes collected by the colonial government was to be allocated to regions on the basis of derivation, while non-regional revenues, which accounted for majority of the national budget was, however, to be shared based on the principle of 'need' and 'national interest'. ${ }^{78}$

\section{Revenue Allocation and Decentralization}

By 1953, there was a need to review the 1951 Macpherson Constitution. This was mainly due to the constitutional developments at the time as well as the growing support for federalism in the country. The need to decentralize governmental powers and distribute the tasks of governance ensured that Nigeria was to become a federal State eventually. Consequently, the Nigeria (Constitution) Order in Council

77 Government of Nigeria, Report of the Commission on Revenue Allocation (Lagos, Government Printer 1951) 84 [hereinafter Hick-Phillipson Report].

78 The report also noted that in a unitary system, such as was practised in Nigeria at the time, the appropriate principles of revenue allocation were, first, grant from the central government to the regions in such a way as to encourage expenditure on sectors of national importance such as education, with care not to create unequal treatment and population and secondly, the use of population. See ibid, 55. However, it thus seems that due to the unreliability of population records at the time, as it is today, the report decided on the use of the number of male adult taxpayers in the regions to estimate the revenue allocation based on size of population. See C. Ashwe, Fiscal Federalism in Nigeria (Centre for Research on Federal Financial Relations, Australian National University, Canberra 1986) 29. 
1954 (Lyttleton Constitution) gave to the regions greater autonomy to make laws for themselves on matters not specifically included in the exclusive legislative list. The regions were also granted the power to legislate on matters contained in the concurrent legislative list. This constitutional power was shared with the federal government.

The constitutional changes brought about by the 1954 Lyttleton Constitution meant that there was a need for a new revenue allocation system for the country. The Chick Commission (chaired by Sir Louis Chick) set up to undertake this task, recommended that less emphasis be placed on 'need' and 'national interest' as determinants for the new revenue allocation system.

In line with the mood of the country, the report indicated a strong preference for fiscal autonomy and emphasized, yet again, the principle of derivation as a basis for revenue sharing. Regrettably, the revenue sharing system recommended by the Chick Commission did not last as it was reviewed in 1958 - which coincided with the period when crude oil was discovered in commercial quantity. For the first time in the history of Nigeria's revenue allocation system, the Raisman Committee of 1958 recommended that the principle of derivation, which hitherto ensured that 100 per cent of the revenues from mining rents and royalties went to the regions be partially discontinued. It did not matter that revenues from oil, at the time, was only 65,000 pounds - an insufficient amount compared to what was earned from other mineral resources. Yet the Raisman Committee noted that the allocation of the proceeds of mining royalties has presented a most perplexing problem because of the discovery of oil. Moreover, fearing that the oil-bearing region may be credited with huge oil income revenues too sizeable to ignore, and coupled with the need for stability and national development, the Committee recommended the discontinuance of the revenue allocation system, which was based on derivation. ${ }^{79}$

At independence, and consolidating on the provisions of the 1954 Lyttleton Constitution, section 134 of the Nigeria (Constitution) Order in Council 1960 (the 1960 Constitution) also made provisions for revenue allocation. That constitutional provision made specific reference to minerals and mineral oil instead of natural resources. This appears to be a measure that was adopted by the government to allow it focus

79 Colonial Office (Nigeria), Report of the Fiscal Commission (Her Majesty's Stationary Office, London 1958) 24 [Raisman Report]. 
on the newly discovered crude oil as a more dependable source of revenue for the national economy. The status quo remained the same under the Constitution of the Federation 1963 (the 1963 Republican Constitution), as the provisions relating to revenue allocation remained unchanged. ${ }^{80}$ However, in a rather dramatic fashion, the Dina Committee on revenue allocation, set up by the General Yakubu Gowon military administration in 1968, recommended the complete discontinuance of the principle of derivation, hinging the reason on the need to promote national integration and development. The report noted that:

'[o]nce it is accepted that the overwhelming social urge is for accelerated economic development as a major prerequisite for expansion of welfare services, then the point must be sustained that financial relations become only meaningful in the context of integrated development planning. ${ }^{81}$

In any case, the above statement does not make any sense in a federal system rather it merely served the end of a unitary system, which the military government at the time needed to quell the Biafra secessionist movement. Besides, this recommendation contradicted the ideology held by Obafemi Awolowo, the then federal finance commissioner. As Awolowo once noted, '[i]t is dishonest to the extreme for a relatively poorer state to expect to have a share from the revenue derived from a relatively richer state. ${ }^{82}$ Nevertheless, in April 1969 the federal government went on to implement the committee's report, even though state commissioners of finance on behalf of the affected oil bearing states rejected its recommendations. The result was the

80 See Constitution of the Federation No. 20 of 1963, s 140; see also Attorney General of the Federation $v$ Attorney General of Abia State (n 66) 99 (Ogundare JSC).

81 Dina Committee Report (1969) 29. The report also stated: '[w]e believe that the fiscal arrangements in this country should reflect the new found spirit of unity to which the nation is dedicated. No more evidence of this is necessary than the present war to preserve this unity at the cost of human lives, material resources and the radical change in this country's structure. It is in the spirit of this new-found unity that we have viewed all the sources of revenue of this country as the common funds of the country to be used for executing the kind of programmes which can maintain this unity' (ibid, 27).

82 Obafemi Awolowo, quoted in O. Obinna, Public Finance (Pacific College Press Limited 1985) 113.

83 Decree No. 51 of 1969.

84 Decree No. 9 of 1971. 
promulgation of the Petroleum Decree $1969^{83}$ and the Offshore Oil Revenue Decree $1971 .{ }^{84}$ It was the later decree that introduced the dichotomy between onshore and offshore oil in the determination of revenue from crude oil and allocated to the federal government the revenues derived from off-shore oil. ${ }^{85}$ Not only has the availability of oil resulted in the distortion of the revenue allocation system in Nigeria, it has also become highly political as '[t] he struggle for the control of the oil wealth has led to an unfortunate shift [in focus] from a revenueoriented principle to an expenditure-oriented principle of revenue allocation'. ${ }^{86}$ This loss of focus has resulted in the impoverishment of the citizens more than they were before oil was discovered. ${ }^{87}$ Despite this gloomy situation, successive governments have continued to promote wasteful policies at the expense of the citizens. Two of such ubiquitous policies in the Nigerian polity are examined in the following section.

\section{THE HIGH COST OF GOVERNANCE}

This article will not attempt an exhaustive examination of the causes of the high cost of governance in Nigeria as there are quite a number of factors. For example, the bloated salaries paid to elected and appointed public office holders constitute one of such aspects. In this section, only two issues - the growth and expansion in governmental structures and the policy of security votes - which promote this trend are examined.

\section{The Growth and Expansion in Governmental Structures $^{88}$}

The cost of governance in Nigeria has, since the 1970s, expanded geometrically whereas the economy has struggled to catch up. This is partly due to the unnecessary expansion in governmental structures,

85 Petroleum Act, s 1.

86 Uche and Uche (n 73) 41.

87 J. Herbst, 'Is Nigeria a Viable State?' (1996) 19 (2) The Washington Quarterly $151,159$.

88 Ukpong (n 64) ch 4.

89 Rationalization of Federal Government Parastatals and Agencies Committee Report (2012) [Oronsanye Report]. 
agencies, and institutions with overlapping functions..$^{89}$ Consequently, the cost to keep the governing process going at all levels has become unsustainable. Yet while a constitutional amendment was underway in the National Assembly in 2014/2015, there were proposals for wives of the president and state governors to be officially recognized under the Constitution, by creating the office of the first lady at the federal and state levels. It would appear that this is a measure to accord constitutional recognition to the hitherto unconstitutional and illegal funding of the activities promoted by the spouses of the president and state governors in Nigeria. Interestingly, there were also proposals from sections of the country for more states to be created out of the existing ones. As things stand today, this appears to be mere wishful thinking as the 2014 National Conference in its resolution urged that, 'without prejudice to states constituting the federating units, states that wish to merge may do so in accordance with the Constitution'. ${ }^{90}$

Political enterprises such as the ones highlighted here contribute in diverting resources away from investments in public goods and services to the expansion of State bureaucracy. In recent times, the debate on the economic non-viability of many states in Nigeria has been in the front burner of national discourse. ${ }^{91}$ According to Sanusi

90 The National Conference 2014, Main Report (Abuja, August 2014) 197.

91 With the inability of many state governments to pay workers' salaries and satisfy other social obligations for several months, they have had to go to the federal government for bailout funds. E. Archibong, 'Bailout: CBN Restructures States' Loan Repayment to 20 Years' Business Day (Lagos, 24 July 2015) < http:/ /businessdayonline.com/2015/07/bailout-cbn-retructures-states-loanrepayment-to-20-years/> accessed 7 August 2015; 'Governors Meet Wednesday, Seek Bailout to Pay Salaries' This Day (Lagos, 17 June 2015) $<$ www.thisdaylive.com/articles/governors-meet-wednesday-seek-bailout-topay-salaries/212244/> accessed 7 August 2015.

92 For example, the 2011 revenue profile of Akwa Ibom, an oil producing state, shows that recurrent revenue was NGN 174.527 billion (12.534 billion from internal sources; 24.714 billion from statutory allocation; 6.452 billion from value added tax (VAT) and 129.060 billion from derivation), while capital receipt was NGN 24.851 billion. See G. O. Akpabio, 'Budget of Industrialization: Text of 2012 Budget Presentation to Akwa Ibom State House of Assembly' Finance News (Ministry of Finance, January 2012) 41. It is obvious from the foregoing that statutory allocation and derivation funds are major sources of revenue for the state. Comparing this with other states besides Lagos, Kano and other oil producing states, it is obvious that more than two thirds of the states in Nigeria are economically non-viable. See for example, the comments by V. I. Masi, minister of finance in the second republic, quoted in Ukpong (n 64) 99. 
Lamido Sanusi, a former governor of the CBN, most states and indeed many local governments in Nigeria are not economically viable, ${ }^{92}$ as a significant amount of their revenues are spent on running the machinery of government while millions of the population are left at the mercy of unemployment and poverty. ${ }^{93}$ Sanusi's comment is a validation of Ross's assertion that governments are affected by the kind of revenues they collect. ${ }^{94}$ For as soon as the Nigerian State began to witness sharp changes in its revenues as a result of the perennial increase in oil prices, government spending began to grow faster than the economy. ${ }^{95}$

Arguably, this has become a frequent trend in Nigeria, with consequent constraints on the capacity of the Nigerian State to meet its obligation of progressive realization of the social and economic aspirations of the citizens who look up to the State for social protection..$^{96}$ This points to a murky situation, which, for Jeffrey Herbst, is a consequence of a particular pattern of Nigeria's politics that threatens even to impoverish the population and to cause a catastrophic collapse of the social and economic structures of the country. ${ }^{97}$ Consequently, Herbst urged the international community to acknowledge that 'Nigeria does not work and probably cannot work', ${ }^{98}$ and to set in motion a rescue mission for the sake of millions of Nigerians and the African continent.

One thing is certain, a State that fails to see the social needs of its citizens as its ultimate priority will never be efficient, and a State that is not efficient is a failed State. Notwithstanding the obvious failure of

93 According to Sanusi, '[d]o we need 36 states [in Nigeria]? Do we need the number of ministries that we have? Is an economy where states spend 96 per cent of their revenue[s] paying civil servants an economy that is likely to grow in the long run? ... We have created states and local governments and ministries as structures that are economically unviable and the result is that we do not have funding for [social] infrastructure, we do not have funding for education; we do not have funding for health. I do not know how many people know that 70 per cent of the revenue of the federal government is spent paying salaries and overhead; leaving the rest of 30 per cent for 150 million Nigerians.' S. L. Sanusi, 'Re-invigorating Education in Nigeria' Daily Times (Lagos, 31 October 2011) < http://dailytimes.com.ng/article/most-our-states-are-not-viable> accessed 28 November 2014.

94 See Ross (n 20) 27.

95 ibid 27-29.

96 Solomon (n 54) 101, 103.

97 Herbst (n 88) 151.

98 ibid. 
the Nigerian State, successive governments allude to economic growth and development as if they occur in a vacuum. Writing on development, Dudley Seers noted that if the social and economic problems of poverty, unemployment, and inequality have declined over time, 'then beyond a doubt this has been a period of development for the country concerned. [Otherwise], it would be strange to attribute such condition as development irrespective of growth in GDP.'99

The point being made here is that economic development is peoplecentred rather than economic growth. This prescription especially holds for a developing country such as Nigeria, where poverty, unemployment, income inequality, high rates of illiteracy and mortality ${ }^{100}$ are serious social problems that "may well serve as indices of good or effective government'. ${ }^{101}$

The question may then be asked: On what should government direct it's spending? According to Michael Ross, oil-rich countries spend oil revenues in two ways. Those with authoritarian regimes spend oil revenues in buying public support to enable those regimes to remain in power as long as they may wish. Therefore, as he noted, '[c] ountries with great per capita oil wealth, like the kingdoms of the Arabian Peninsula provide their citizens with a remarkable portfolio of free benefits, such as education through college, free health care, and subsidized food and housing. ${ }^{102}$ In the alternative, he argued that the oil revenues are simply lost to State theft. This holds true for Nigeria, as 'wealth is substantially gained through military might or strategic political position' which necessitates the struggle for State power that can promote resource capture - a benefit only State power confers. ${ }^{103}$

Ross qualified the developmental capacity of oil-rich States by

99 Seers quoted in Ukpong (n 64).

100 For the updated data on infant mortality rate in Nigeria as at 2015, see Central Intelligence Agency, 'Infant Mortality Rate' in The World Factbook <www.cia.gov/library/publications/the-world-factbook/fields/2091.html> accessed 19 December 2015); Central Intelligence Agency, 'Life Expectancy at Birth' in The World Factbook <www.cia.gov/library/publications/the-worldfactbook/rankorder/2012rank.html> accessed 19 December 2015.

101 Ukpong (n 64) 83.

102 Ross (n 20) 78.

103 E. Nnadozie, 'Are Growth and Development Constitutional Issues in Nigeria?' (paper presented at the CSAE sixth annual conference, Understanding Poverty and Growth in Sub-Saharan Africa, St Catherine's College, Oxford, 18 \& 19 March 2002) 6. 
suggesting that the size of the population of an oil-rich country may have some role to play in the efficient application of oil revenues. Going by this argument, it is safe to say that Nigeria is a country with very low per capita income despite its huge oil endowment because of its fast growing population in contrast to the tiny population of the oil-rich Arabian nations. This suggests that Nigeria may, after all, not be a rich country. If this is the case, and the facts are available to policy makers, why have they failed to promote policies that would stimulate the other sectors of the economy?

The foregoing argument notwithstanding, the challenges posed to the sustainable management of oil wealth in Nigeria have been greatly attributed to the social maladies of corruption (a crime with victims, citizens, who are unable to realize their full potentials) and waste in the governing process. For example, when the military first entered governance in 1966, it accused the politicians of the First Republic of political corruption. The allegation of graft and misuse of public funds was also levelled against the military administration of General Gowon when it was overthrown in a bloodless coup in $1975 .{ }^{104}$

The story has remained the same since the return to civilian rule in 1999, with each successive administration accusing the preceding one of waste, mismanagement and State theft. ${ }^{105}$ It is on record that only the administration of former President Olusegun Obasanjo (1999-2007) refrained from levelling accusations of waste, misuse of public funds and corruption against the administration immediately preceding it, even though revelations in the public domain reveal otherwise. The presidential system was first practised in Nigeria between 1979 and 1983. The huge financial resources deployed in running the system did not match the social and economic realities of the country at the time and '[a]t the end of the first four years, the presidential system and the realities of the Nigerian society seem to have functioned on two mutually exclusive planes of affluence and poverty.' ${ }^{106}$ Examining the flamboyance of the presidential democracy of 1979 to 1983 in relation to the level of economic performance, Ukpong identified that

104 M. Mohammed, 'A Time for Action' (A Broadcast Speech to the Nation, 30 July 1975) 8, 15.

105 P. Smith, 'Honeymoon Over' The Africa Report (Paris, July-August 2016) 50, 51; O. Egbo et al, 'Security Votes in Nigeria: Disguising Stealing from the Public Purse' (2012) 111 (445) African Affairs, 607.

106 Ukpong (n 64) 133.

107 ibid 134. 
there was a linkage between oil wealth, politics and the legal regime, which established the Presidential System. ${ }^{107}$

\section{The Policy of Security Votes}

Various definitions have been proffered on the meaning of security votes. While some see security votes as the unconstitutional appropriation by all tiers of government in Nigeria for the purpose of ensuring national security, ${ }^{108}$ others have described it as a conduit for graft under the guise of enhancing national security. ${ }^{109}$ Research has shown that some of the definitions may not stand the test of law. Therefore, the policy of security votes, as practised in Nigeria, may be defined as an omnibus expenditure heading under which public funds are appropriated, through budgetary and extra-budgetary measures, by all levels of government in Nigeria for the purpose of enhancing state security.

Since the return to civilian rule in 1999 (the Fourth Republic), security votes have remained a recurrent discourse in Nigeria. Each year, huge public funds are secured at all levels of government in Nigeria in the name of security votes. ${ }^{110}$ These funds are purportedly appropriated for State security. In spite of these huge expenditures on security, social vices such as kidnappings, cultism, assassinations, robbery and others are rife all across the country. The question may then be asked: Whose interest is served with the allocation and appropriation of security votes - the citizens or public office holders who are directly entrusted with the funds? At the federal level, funds

108 C. Kumolu, 'Insecurity: What has the Security Vote Secured? Vanguard (Lagos, 15 May 2013) <www.vanguardngr.com/2013/05/insecurity-what-has-thesecurity-votes-secured/> accessed 2 November 2014.

109 O. Egbo et al, 'Institutionalizing Corruption: Security Votes in Nigeria' (African Studies Centre, Leiden, The Netherland, ASC Working Paper 91/2010) 4, available at <https://openaccess.leidenuniv.nl/bitstream/handle/1887/ 16186/ASC-075287668-278801.pdf?sequence $=2>$ accessed 30 October 2014.

110 O. Egbo et al, 'Security Votes in Nigeria: Disguising Stealing from the Public Purse' (n 103)597-614, for the history and practice of security votes, as well as the ambiguity, secrecy and unaccountability associated with it at all levels of government in Nigeria.

111 The sums of N264 billion, N348 billion, N921.91 billion, N1.05 trillion and N968.13 billion were approved by the National Assembly in the Appropriation Acts of 2010, 2011, 2012, 2013 and 2014 respectively for security. 
are allocated each year to the ministry of defence and other security agencies in the appropriation law, ${ }^{111}$ 'as national security is the exclusive responsibility of the federal government'. ${ }^{112}$ Yet state governors and local government chairmen appropriate massive funds each year under the security vote expenditure head.

While a few state governments include security vote expenditures in their annual appropriation laws, ${ }^{113}$ the majority of the states do not disclose how much funds are allocated and expended as security votes. There is no accountability, in whatever form, to the public. Therefore, it has been argued that security votes are channels that allow some elected public officers to misappropriate and, in most cases, steal public funds outright.

In a dramatic fashion, Musa Rabiu Kwankwaso, a former governor of Kano State and Rochas Okorocha, the incumbent governor of Imo State, aroused public interest in security vote expenditures with their unprecedented declarations on these funds shortly after they took the oath of office in 2011. Governor Kwakwanso, who was first elected to office from 1999-2003, described security votes as another way of stealing public funds and vowed not to have anything to do with it. Governor Okorocha, on the other hand, slashed his state's annual security votes from N6.5 billion to N2.5 billion and noted that he was freeing the gains made in the cut for education and other social programmes that are in dire need of funding. The amount appropriated as security votes by state governments in Nigeria range between N400 million and N2 billion on a monthly basis. Over N1.5 trillion is allocated and expended annually as security votes by governments at all levels in Nigeria, virtually all of which is lost to corruption. ${ }^{114}$

Some legal and social commentators have argued that security votes are illegal and unconstitutional and that the practice is the height of irresponsibility on the part of all governments in the Federation. This

112 O. Egbo et al, (n 106) 608.

113 Section 1 of the Lagos State Security Trust Fund Law 2007, established a trust fund in Lagos state for 'response to the operational deficiency of the Police and other federal security agencies within the state due to long years of neglect by the federal government, particularly in the areas of funding and provision of modern equipment.' See Lagos State Security Trust Fund, available at $<$ www.lagosstatesecuritytrustfund.org/profile> accessed 28 September 2015.

114 Chicago Tribune, available at <my.chicagotribune.com/\#section/-1/article/ p2p-85074850/> accessed 22 November 2015. 
argument is anchored on the fact that section 14(2)(b) of the Nigerian Constitution, or any other section of the Constitution for that matter, does not provide that security votes should be allocated to elected public officers to appropriate as they see fit. On the other hand, there is the argument that ' $\mathrm{t}]$ he most general purpose of [S] tate power is to provide security for citizens and other residents and to enable them lead a life that is meaningful to them'. ${ }^{115}$ The second argument finds support in the Nigerian Constitution to the extent that 'the security and welfare of the people shall be the primary purpose of government'. ${ }^{116}$ It is this normative and constitutional requirement that reinforces the argument that there exist both legal and constitutional bases for the policy of security votes in Nigeria.

The apprehension generated by the policy of security votes in Nigeria, in recent times, are not misplaced as it is the vulnerable in society who are most affected by anti-social policies. In recognition of this, Nkereuwem Akpan, an Abuja-based legal practitioner and human rights activist, commenced a lawsuit at the Federal High Court, Abuja, in 2010. In the suit, he sought a declaratory order against the 36 state governors and the Minister of the Federal Capital Territory (FCT) in relation to the legality and constitutionality of security votes drawn from the public treasury of the states and the FCT, respectively. ${ }^{117}$ In his statement of claim, the plaintiff asserted that no law in Nigeria, including the Constitution, recognizes the policy of security votes. The plaintiff, therefore, urged the court to declare the action of the

115 P. Y. Ghai and J. Ghai, MDGs through Socio-economic Rights: Constitution Making and Implementation Handbook (Excerpt) (United Nations Millennium Campaign, Bangkok 2009) 20.

116 Nigerian Constitution, s 14(2)(b).

117 Nkereuwem Udofia Akpan v Executive Governor of Abia State \& 38 Ors (Suit No.FHC/ABJ/CS/753/2010) [Unreported]. In its judgment, the Court held that the plaintiff could only bring the suit against the state governments in their respective states. This would be almost impossible to do as he would be required to bring 36 lawsuits across the country. Besides, the plaintiff, or anyone for that matter, could not do so because there is no equivalent of the Fiscal Responsibility Act in most of the states.

118 The 3rd defendant raised a preliminary objection that the plaintiff lacked the locus standi to institute the suit. However, by the provision of sections 36(1), 40, 4142 and 48 of the Fiscal Responsibility Act Cap F40LFN 2004, it appears that the plaintiff has standing to institute the suit, but, it should be noted that the provisions of the Act as depicted in the long title and explanatory memorandum to the Act does not apply to the states that have not passed the Fiscal Responsibility Law in their states. And a great number of them have not. 
defendants as illegal and unconstitutional. ${ }^{118}$

In the statement of defence filed by the Akwa Ibom State Ministry of Justice for the third defendant (governor of Akwa Ibom State), it was contended, among other things, that the security votes collected by the governor, deputy governor and speaker of the state House of Assembly are legal and constitutional as they have legislative backing by way of appropriation laws, ${ }^{119}$ which were legally passed by the Akwa Ibom State House of Assembly pursuant to sections 100 and 120(2) of the 1999 Constitution. These provisions in the Nigerian Constitution confer on state legislatures the power to make laws for the states.

The combined effect of sections 59 and 100 of the Nigerian Constitution, section 56 of the Fiscal Responsibility Act and section 18 of the Interpretation Act make it clear that security votes, when legally budgeted and appropriated becomes a lawful expenditure. For when the Legislature approves a money bill and it receives the assent of the president or governor, as the case may be, it becomes law. It is, therefore, submitted that although the Nigerian Constitution does not expressly provide for security votes, it could be inferred from the provisions of section 14(2)(b) of the Constitution that security votes constitute permissible expenditures. ${ }^{120}$

The policy of security votes appears to have legal and constitutional backing beyond the permissibility argument. Also problematic is the misapplication of the provision of section 14(2)(b) of the Constitution, as it is the security of the citizens that is intended and not the security of select individuals in public office as the practice in Nigeria suggests. Perhaps, as one writer has suggested, the justification for this practice may well be that governments in Nigeria wish to rearrange Maslow's hierarchy of needs by realizing the needs of citizens starting with security rather than basic needs such as ensuring food security, drinkable water, decent housing, healthcare, quality education and employment opportunities. ${ }^{121}$

Besides, the legal and constitutional issues, which have been raised

119 Interpretation Act Cap I23 LFN 2004, s 18 and Fiscal Responsibility Act, s 56, for the meaning of Appropriation Law.

120 The principle for the permissibility argument under the Nigerian Constitution is briefly discussed in Solomon (n 54) 113-114.

121 A. Ogbodo, 'Security Votes as Governors 'Awoof' Money' The Guardian (Lagos, 1 July 2012) available at <www.ngrguardiannews.com/index.php?option=com content\&view = article\&id = 90887: security-votes-as-governors-awoofmoney\&catid=104:sunday-magazine\&Itemid =567> accessed 29 July 2012 . 
in respect of the policy of security votes, other fundamental issues such as the appropriate authority that should be responsible for the expenditure of the funds and how they should be expended remain unresolved. For example, in the US from where the practice may have derived, security votes are predicated on covert diplomatic intelligence activities. Each year, the appropriation committees of the US Congress appropriate funds for the Central Intelligence Agency (CIA). The CIA is an independent agency responsible for providing national security intelligence to senior US policymakers. ${ }^{122}$ The funds allocated to the CIA are specifically devoted to espionage and other covert operations. Owing to the surreptitious nature of its assignments, it is not expected to, and does not, publicly account for its budgetary votes. The CIA budget is secret, and the agency is allowed to keep its staffing, organizational structure, salaries and number of its employees secret. ${ }^{123}$ It only briefs the select committees of the US Congress (the House Permanent Select Committee on Intelligence and the Senate Select Committee on Intelligence) whose members are sworn to secrecy. According to The World Factbook, '[i]n 1997, the total budget for all US government intelligence and intelligence-related activities - of which the CIA is a part - was [US\$] 26.6 billion. [However] the intelligence budgets for all other years remain classified.' ${ }^{124}$ For many years, during and after the Cold War, the agency's primary mission was to protect the US against communism and the Soviet Union. Notably, these days, the agency has an even more complex job, which is to protect the US from terrorist threats all over the world. ${ }^{125}$

In contrast, Nigeria's mutated security vote policy and practice entrusts the discretionary powers to spend huge public funds on certain elected public officials who may not have any idea of operational issues on security matters. In the country, security votes are allocated to the president, heads of the two chambers of the National Assembly, state

122 Central Intelligence Agency, 'Today's CIA' The World Factbook<www.cia.gov/ about-cia/todays-cia/index.html> accessed 30 June 2012.

123 Central Intelligence Agency Act of 1949, Pub L 110, 63 Stat 208 (50 USC 403a etseq) s 6.

124 Central Intelligence Agency, The World Factbook< <ww.cia.gov/about-cia/faqs/ index.html\#whoworks > accessed 30 June 2012 (emphasis added).

125 C. Wilbert, 'How the CIA Works' < https://people.howstuffworks.com/cia.htm> accessed 30 June 2012. 
governors, speakers of state Houses of Assembly and chairpersons of local government councils. ${ }^{126}$ In some cases, with the discretion of the president and state governors, the vice-president, the secretary to the government of the federation (SGF), deputy governors and secretaries to state governments also benefit from the security vote policy. These funds are spent entirely at the discretion of the holder of the office. This policy and practice, which unnecessarily increases the cost of democratic governance in Nigeria, has become endemic and promotes state theft through the secrecy in which the budgeting, allocation and appropriation of the funds are shrouded. ${ }^{127}$

It is obvious from the scanty data on security vote allocations that many state governments do not include security vote expenditures in their appropriation laws, as they prefer to apply extra-budgetary measures in the allocation of such funds. ${ }^{128}$ This ensures that the public is kept out of the loop on this bogus expenditure. An example of governments' secrecy policy on security votes was demonstrated by the responses of the accountants general of Kwara and Delta states to an application made by the Legal Defence and Assistance Project (LEDAP), a CSO, requesting for information from all the 36 states of the Federation in respect of security vote expenditures, pursuant to section 1 of the Freedom of Information Act 2011. ${ }^{129}$ In response to the application, the accountants general of the two states stated that the information sought by LEDAP were exempted by the Act and therefore noted that they were not at liberty to provide the information

126 Human Rights Watch, 'Chop Fine: The Human Rights Impact of Local Government Corruption and Mismanagement in Rivers State, Nigeria', (2007) 19(2a) Human Rights Watch 32-3, for an analysis of how local government authorities in Nigeria deprive the people of social amenities.

127 For an analysis of the linkage between security votes and corruption in Nigeria, see O Egbo, 'Legitimizing Corruption in Government: Security Votes in Nigeria' (2010) African Studies Centre Working Paper 91/2010 available at <https:/ /openaccess.leidenuniv.nl/bitstream/handle/1887/16186/ASC-0752876682788-01.pdf? sequence $=2>$ accessed 29 September 2013.

128 Punch on the Web, 'Governors Hide Security Votes' <www.punchng.com/ Articl,aspx? theartic $=$ Art201107164312492 $>$ accessed 2 September 2013; Business Day, 'Security Votes for Who?' <www.businessdayonline.com/NG/ index.php/editorial/24034-security-vote-for-who $>$ accessed 9 September 2013; The Will, 'State Governors and their Security Votes' <http:// thewillnigeria.com/opinion/6671-STATE-GOVERNORS-AND-THEIRSECURITY-VOTES.html> accessed10 June 2013.

129 Freedom of Information Act Cap F43 LFN 2004. 
to LEDAP.

On the other hand, the accountants general of the remaining 34 states refused out-right to respond to the application. Consequently, LEDAP commenced an action at the Federal High Court, Lagos, on 6 July 2011, for an order of mandamus to compel the accountants general of the 36 states of the Federation to furnish it with information on the security votes allocated and released to the governors, deputy governors and speakers of the state Houses of Assembly.

The Freedom of Information Act provides that the court can order an institution to which a request for information was made, but refused or failed to provide the information within the period prescribed by the Act, to release such information. ${ }^{130}$ It should be noted that the information requested by LEDAP is not exempted under the Act as claimed by the accountants general of Kwara and Delta States. Indeed it is not a course or research material prepared by faculty members of educational institutions, published material or material available for purchase by the public, library or museum material made or acquired and preserved for public reference or exhibition, or material placed in the National Archives. ${ }^{131}$ The official secrecy of the policy at all levels of government in Nigeria only validates the damning conclusion reached by a study that ' $[t]$ he greater the oil wealth is, the more secretive the budget. The secrecy of ... oil producers is especially pronounced [in] opaque governments - Angola, Chad, Nigeria, and Cameroon ... [And] the five most transparent in Africa-South Africa, Botswana, Zambia, Uganda, and Namibia - have little or no petroleum. ${ }^{132}$

\section{FUTURE DIRECTIONS}

The purpose of this section is to examine the future directions for the management of Nigeria's oil wealth. The future direction requires a two-level approach consisting of legal and extra-legal measures - each of which may have an impact on the other. In a bid to effectively play the role of a developmental state, Nigeria has deployed some legal measures in the regulation of the oil and gas sector in the past. The

130 ibid, ss 20 and 25.

131 ibid, ss 17 and 26.

132 Ross (n 20) 81 (emphasis added). 
first of such measures involved taking greater control of the Nigerian oil and gas industry. ${ }^{133}$ This measure sought to directly increase and enhance the State's interests in the oil and gas sector. It is also aimed at ensuring that a greater share of revenues from oil exploration and for improved provision of public goods and services.

Observably, there are consistent claims that the national oil company fails or refuses to transfer tens of billions of dollars in oil revenues to the national treasury each year. In most cases the whereabouts of these funds are never properly accounted for. ${ }^{134}$ Many commentators have argued that the NNPC is the single most corrupt organization in Nigeria as it has, over the years, become too complex for its activities to be properly monitored. ${ }^{135}$ Arguably, this has implications for the funding of the upstream sector as the government which is often faced with the challenge of meeting its Joint Venture funding obligations. ${ }^{136}$ This situation has led to the increased utilization of measures such as the Petroleum Sharing Contract (PSC) and Modified Carried Agreement (MCA), which, to a large extent, have contributed to undermining the State's interest in the oil and gas sector. ${ }^{137}$ The complex nature of the NNPC in respect of its various activities in the oil and gas sector has made it difficult for the Nigerian Extractive Industries Transparency Initiative (NEITI) to deliver on its mandate to improve transparency and accountability in the management of revenues from Nigeria's extractive resources. ${ }^{138}$ The mandate of the NEITI is to ensure that companies operating in the extractive industry

133 KPMG Professional Services, 'Nigerian Oil and Gas Industry Brief' (KPMG Nigeria June 2014) 10 <www.kpmg.com/NG/en/IssuesAndInsights/ ArticlesPublications/Documents/Nigerian\%20oil\%20and\%20gas\%20Industry \%20brief.pdf $>$ accessed 21 August 2016.

134 B. Udo, 'Missing \$20 bn: Sanusi Faults Alison-Madueke, Says Audit Report Proves at Least $\$ 18.5$ bn Lost' Premium Times (Abuja, 14 May 2015) $<$ www.premiumtimesng.com/news/182926-missing-20-bn-sanusi-faultsalison-madueke-says-audit-report-proves-at-least-18-5bn-lost.html >accessed 2 August 2016; O. Nnodim, 'We Owe Federation Account N326 bn, Not N3.23 trn - NNPC' Punch (17 March 2016).

135 I. Izeze, 'NEITI's Recant on NNPC's Unremitted \$22.8 Billion: Shame of a Corrupt Nation' Point Blank News (26 March 2014) <pointblanknews.com/ $\mathrm{pbn} /$ articles-opinions/neitis-recant-onnnpcs-unremitted-22-8-billion-shameof-a-corrupt-nation/> accessed 20 July 2016.

136 KPMG Professional Services (n 134) 19.

137 Sharife, 'How Nigeria's Lucrative Oil Profits Disappear' (n 34).

138 NEITI Act, s 2. 
follow due process in the payments of revenues into the public treasury. Therefore, there is a need for the urgent unbundling of the NNPC and its subsidiaries into smaller and manageable corporations ${ }^{139}$ devoid of overlapping functions in the oil and gas industry, and with legislative control over their activities.

There is also the application of the legal approach to enhance local participation in the oil and gas sector through the local content requirement which is aimed at increasing the 'level of Nigerian Content in the country's oil and gas industry', ${ }^{140}$ by 'demanding that a certain percentage of intermediate goods used in the [oil] production processes [are] sourced from domestic manufacturers. ${ }^{141}$ In line with this policy, the Nigerian Oil and Gas Industry Content Development Act (NOGIC Act) defines Nigerian Content as

the quantum of composite value added to or created in the Nigerian economy by a systematic development of capacity and capabilities through the deliberate utilization of Nigerian human material resources and service in the Nigerian oil and gas industry. ${ }^{142}$

The NOGIC Act makes provisions for the first consideration of Nigerian independent operators, goods, and services as well as to Nigerians in employment and training. ${ }^{143}$ The law also covers all fabrications and welding activities in the oil and gas industry, which must be done in the Nigeria. ${ }^{144}$ Observably, the efficacy of this strategy is yet to be felt on employment opportunities, as the Nigerian oil and gas industry created only 582 jobs of the 10.97 million new jobs in

139 O. Nnodim and F. Asu, 'FG to Spilt NNPC into 30 Firms Next Week' Punch (Lagos, 4 March 2014) <punchng.com/fg-to-split-nnpc-into-30-firms-nextweek/> accessed 15 June 2016.

140 Nigerian Oil and Gas Industry Content Development Act No. 2 of 2010; KPMG Professional Services (n 134) 17.

141 S. M. Stephenson, 'Addressing Local Content Requirements: Current Challenges and Future Opportunities' (2013) 7(3) BIORES < www.ictsd.org/bridges-news/ biores/news/addressing-local-content-reguirements-current-challenges-andfuture-opportunities $>$ accessed 21 August 2016.

142 NOGIC Act, s 3.

143 ibid ss 10, 12, 15, 28 and 35.

144 ibid s 41.

145 M. Eboh, 'Unemployment: Oil Sector Employs 0.01\% of Nigerian Workforce' Vanguard (Lagos, 3 June 2014)<www.vanguardngr.com/2014/06/ unemployment-oil-sector-employs-0.0i-nigerian-workforce/ $>$ accessed 20 August 2016. 
$2013^{145}$ and out of a total of 41,672 new jobs generated in the third quarter of 2015, the oil sector recorded zero. ${ }^{146}$ Low crude oil prices have worsened the situation as the sector has recorded huge job losses since 2015.

Thirdly, evidence on the ground shows an acute shortage of infrastructure-focused investments - with the capacity to boost other sectors of the economy - in the oil and gas industry. ${ }^{147}$ Infrastructural focused investment is a measure of the potential for sectoral and developmental linkages between oil and gas revenues and research and development, as well as other socio-economic indicators. If properly implemented this third measure has the potential to increase real benefits from oil resource by trickling down the gains of oil wealth regarding improving the social and economic condition of citizens. Fourthly, and also very central to the sustainable management of Nigeria's oil wealth are issues relating to good governance. For some scholars and commentators, regarding the sustainable management of resource-based wealth, transparency, and accountability (or the lack of these) in governance have been identified as very critical issues, which add to resource-driven development processes. These issues can be located at the core of the resource curse thesis. ${ }^{148}$

This article has so far demonstrated that this argument comes into sight for Nigeria. Therefore, the vigilance of the citizens and CSOs is required to keep State institutions and companies in the extractive industry in check. It is recommended that NEITI should be empowered, through legislative amendment, to transmit from being a mere watch dog of the oil and gas industry to an institution with prosecutory authority to protect the public interest in the management of extractive resources in Nigeria.

146 National Bureau of Statistics, Employment (Job) Creation Survey, 3rd Quarter 2015 (November 2015) <www.nigeriastat.gov.ng/pdfuploads/Job_Creation Q3_2015.pdf> accessed 19 August 2016.

147 H. Besada and P. Martin, 'Mining Codes in Africa: Emergence of a 'Fourth' Generation?' (2015) 28(2) Cambridge Review of International Affairs263, 276; KPMG Professional Services (n 134)19.

148 Ross, The Oil Curse: How Petroleum Wealth Shapes the Development of Nations (n 20) ch 2; R Auty, Sustainable Development in Mineral Economies: The Resource Curse Thesis (Routledge 1993). 


\section{CONCLUSION}

The permissive role of weak state institutions, lack of transparency and accountability in governance, and the absence of detailed legal framework on sustainable resource management have created the right atmosphere for the continued unsustainable management of oil wealth in Nigeria. Furthermore, the proliferation of unproductive and resourcesinking administrative units, governmental corruption and misappropriation of funds, and the failure to create a linkage between oil revenues and high economic performance have combined to make the Nigerian State nothing more than an oil selling enterprise. ${ }^{149}$ This reality calls for urgent and radical reform of extant resource laws and institutions in Nigeria to mainstream and reinforce sustainable oil wealth management.

There is also an important role for the Nigerian public in acting as active gatekeepers for accountability and transparency in Nigeria's oil sector. Citizens cannot continue to remain complacent in the hope that the State and its institutions will function in their interest, even as the courts continue to hold onto legalistic and formalistic procedures. The Nigerian public must, therefore, realize that social change in Nigeria can be guaranteed by their resolve to aspire and demand policies and laws which are capable of engendering high economic performance in Nigeria. To this end, CSOs and the media can do more to provide the momentum that is required for social change in Nigeria. This includes providing citizens with adequate and reliable information on how policies and laws that may be put in place for the management of oil revenues affect their lives. ${ }^{150}$

149 J. Alabi, 'Special Report: Unbundling the 'Missing' \$20bn Oil Fund Mystery' Energy News (Lagos, 26 February 2015) < energynews-ng.com/special-reportunbundling-the-missing-20bn-oil-fund-mystery/> accessed 21 November 2015.

150 J. Hatchard, Combating Corruption: Legal Approaches to Supporting Good Governance andIntegrity in Africa (Edward Elgar Publishing Limited 2014) 75; see also Damilola Olawuyi, Principles of Nigerian Environmental Law (Afe Babalola University Press 2015) 150-155. 